Luxurious Networks 



\section{Luxurious Networks}

SALT MERCHANTS, STATUS, A N D STATECRAFT I N

E I G H T E N T H - C E N T U R Y C H I N A

Yulian Wu

$S$ TANFORD UNIVERSITY PRESS

S T A N F OR D, C A L I F O R N I A 
Stanford University Press

Stanford, California

(C) 2017 by the Board of Trustees of the Leland Stanford Junior University. All rights reserved.

No part of this book may be reproduced or transmitted in any form or by any means, electronic or mechanical, including photocopying and recording, or in any information storage or retrieval system without the prior written permission of Stanford University Press.

Printed in the United States of America on acid-free, archival-quality paper

Library of Congress Cataloging-in-Publication Data

Names: Wu, Yulian (Historian), author.

Title: Luxurious networks : salt merchants, status, and statecraft in eighteenth-century China / Yulian Wu.

Description: Stanford, California : Stanford University Press, 20I6. I Includes bibliographical references and index.

Identifiers: LCCN 2016017669 (print) | LCCN 2016020969 (e-book) | ISBN 9780804798II2 (cloth : alk. paper) I ISBN 978I503600799 (e-book) I ISBN 9781503600799 (e-book)

Subjects: LCSH: Merchants—China-Huizhou Diqu—History—I8th century. I Merchants—Social networks—China-History—I8th century. I Manchus-ChinaKings and rulers-History-I8th century. I Material culture-China-HistoryI8th century. I Huizhou Diqu (China)—History—I8th century. I China-HistoryQing dynasty, I644-I9I2.

Classification: LCC DS754.I2 .W8 2016 (print) I LCC DS754.I2 (e-book) | DDC 38I $/ .456644095 \mathrm{I}-\mathrm{dc2} 3$

LC record available at https://lccn.loc.gov/2016017669

Typeset by Newgen in II/I4 Adobe Garamond 
To my mother and father,

Zhu Lijie 朱麗潔 and Wu Zhenyi 吳振義 for everything. 
